\title{
Too many workers or not enough land? The experience of land reform in Spain during the 1930s
}

\author{
JAMES SimpSOn \& JUAN CARMONA
}

KEYWORDS: land reform, rural conflict, Spain, Second Republic. JEL CODES: N54, O13, Q15, R52.

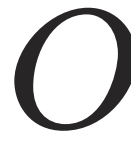

$n$ the eve of the Second Republic enormous estates were believed to be undercultivated by their absentee owners, denying landless workers employment, and leading to widespread rural poverty in southern Spain. The slow implementation of a land reform deeply divided Spanish society, and is often cited as a cause of the outbreak of the Civil War. This paper, using a large sample of farm level information collected by the Institute of Agrarian Reform for the estates expropriated in the region of Extremadura, questions whether large farms were poorly cultivated, and argues that not only did the state lack the capacity to carry out a major reform, but that there was insufficient land available to solve the problems of underemployed rural workers. 


\section{¿Demasiados hombres o tierras insuficientes? \\ La experiencia de la reforma agraria en España en la década de 1930}

\section{PALABRAS CLAVE: reforma agraria, conflicto rural, España, Se- gunda República.}

\section{CÓDIGOS JEL: N54, O13, Q15, R52.}

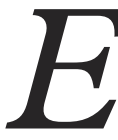

n vísperas de la Segunda República existía un amplio consenso entre la mayoría de los contemporáneos de que era necesario algún tipo de reforma agraria para las provincias del sur de España. Se creía que las grandes propiedades estaban siendo cultivadas de manera demasiado extensiva por propietarios generalmente absentistas, negándoles asi a numerosos trabajadores el acceso al trabajo, lo que llevaría a una extensa pobreza rural. La lenta implementación de la reforma agraria dividió profundamente a la sociedad española, y se ha considerado como la causa de la Guerra Civil. En este trabajo, a través del uso de una amplia muestra de información a nivel de explotaciones individuales recogida por el Instituto de Reforma Agraria para las propiedades expropiadas en la región de Extremadura, se arguye que los intentos de reforma agraria no solo eran un sistema ineficiente para incrementar la producción y la productividad, sino que fracasaron en proporcionar una solución adecuada a la pobreza rural.

Received: 2016-01-27 - Revised: 2016-10-20 - Accepted: 2016-10-24

James Simpson is Professor of Economic History in Universidad Carlos III de Madrid. Address: Departamento de Ciencias Sociales, Universidad Carlos III de Madrid, c/ Madrid, 135, 28903 Getafe (Madrid, Spain).Email:james.simpson@uc3m.es

Juan Carmona is Associate Professor of Economic History in Universidad Carlos III de Madrid. Address: Departamento de Ciencias Sociales, Universidad Carlos III de Madrid, C/ Madrid, 135, 28903 Getafe (Madrid, Spain).Email:juan.carmona@uc3m.es 


\section{INTRODUCTION}

The failure to carry out a comprehensive land reform and break-up the large estates in southern Spain is often cited as a major cause of the outbreak of the Civil War (1936-39). Malefakis (1970: 6), for example, wrote that the study of the agrarian problem, given its overwhelming political importance, implies at the same time an examination of the origins of the Spanish Civil War; while Paul Preston (1984: 160) notes that no single area of social or ideological confrontation during the 1930s matched in scope or impact the agrarian problem. The slow implementation of land reform is usually attributed to a combination of factors, including the lack of political will on the part of the Azaña government (193133), the concerted opposition by the Right, and the self-imposed budgetary constraints caused by a failure to break with orthodox economic policies ${ }^{1}$.

Yet there were other reasons. López Ontiveros and Mata Olmo, in a study of agronomists' proposals for land reform in the fertile Guadalquivir valley (Campiña) around Córdoba, showed that many of the confiscated estates were already intensely cultivated, especially those close to urban settlements, and there were few obvious possibilities to increase output and employment in the short-run. As a result, the provincial agronomist argued that considerably more land had to be expropriated than planned under the 1932 Land Reform Act if all the landless were to be settled (López Ontiveros \& Mata, 1993: 90, 106, 127)2 . Few contemporaries, and perhaps even fewer historians, have accepted these restrictions, and even those that questioned the possibilities of settling large numbers on the relatively capital intensive farms of the Campiña, believed that significant possibilities existed on the hills and upland regions of southern Spain (especially in Extremadura, Western Mancha and Sierra Morena), where cultivation was much more extensive ${ }^{3}$. This paper looks at the settlements in Extremadura where farming was still labour intensive in the 1930s, and contemporaries believed that large areas of its pastures could be converted to arable. In addition, a significant number of the poor were tenants or sharecroppers, and therefore already accustomed to organizing farm production themselves, unlike the landless workers on the Campiña. The region also experienced land invasions

1. Some opposition was also found within the government agency (Instituto de Reforma Agraria) for carrying out the land reform (ROBLEDO, 2014). For budgetary restrictions, see RoBLEDO (2010: 137-44). NAREDO and GONZÁlez DE MOLINA (2002: 99-100) discuss the contradictions of land reform to resolve short and long-term problems.

2. Díaz Del Moral (1973: 37), the Socialist notary from Bujalance (Córdoba), in his classic work on rural protest argued that rapid changes in farming methods had taken place on Córdoba's cortijos since the turn of the century. For a recent survey of agricultural change, LóPEz EstudiLlo (2002).

3. Candu and De la Puerta, for example, writing in 1919, clearly distinguished between the possibilities for settling landless in the Campiña and the Sierra (Florencio, 1994: 320). 
in 1932 and 1936, which suggests an active interest in land reform that was sometimes missing in Andalucia ${ }^{4}$. Despite these apparently favourable conditions, this paper argues that, just as on the Campiña, the lack of suitable land to settle sufficient workers caused major problems in Extremadura. Using farm-level studies carried out by the state organisation, the Instituto de Reforma Agraria (hereafter IRA), it argues that there were few possibilities to extend the area under the plough or intensify cultivation, and that the extensive rotations found were usually considered by agronomists as being rational given the soil quality and farm-gate prices 5 . In part this was because there were few obvious technical possibilities for increasing output at the time, but also because landless workers were settled on plots that were too small to support a family, while the fact that the land did not belong to the settler implied that it could not be used as collateral to obtain loans. Therefore the positive incentives to good cultivation which are often associated with the independent family farm were absent, and the state was required to assume many of the functions that the absentee landowners had previously performed. The result was that land reform implied the substitution of one absentee landlord for another. Finally the manner by which land reform was implemented created tensions because of the often contradictory political demands to resolve short-term problems of unemployment and poverty with those of increasing long-term output, problems which were unlikely to have been resolved even if the Civil War had not halted its progress.

This paper has four sections. The first considers briefly the economic logic behind a land reform, and examines the Spanish experience in the 1930s. This is followed by a study of land availability and the numbers that needed to be settled. The state had poor information on both, but a truly massive redistribution of property would have been necessary if workers were to be given sufficient land to cover even basic subsistence. Section three examines the implementation of land reform in the province of Badajoz in the Extremadura region, and shows that there were limited possibilities to increase output by intensifying cultivation. Finally, section four argues that the failure to give each family sufficient land resulted in the underemployment of labour, work animals and farm machinery, changing the nature of transaction costs associated with using labour, rather than reducing them. The last section concludes.

4. For the reluctance of the anarchist landless workers to be settled in Jerez de la Frontera, see CARO (2001: 196-208).

5. Documents are located in the archive of IRA (hereafter AIRA). For Badajoz, information is available for 30 settlements, and includes documents associated with the expropriation of each farm; the technical reports on how it was farmed, and its future potential; the selection of families; the handing over of the new settlement and the accounts and correspondence with the IRA (MARTÍN, 1997). 


\section{WHY LAND REFORM? POVERTY AND PROPERTY OWNERSHIP IN SOUTHERN SPAIN}

In 1919 the agronomist Pascual Carrión advanced ideas for a land reform and the benefits from creating independent, family farms, which echo some of those used today by institutional economists ${ }^{6}$. He argued that farm work, unlike industrial work, was highly diverse, and it was difficult to create an incentive structure for wage workers to carry out tasks quickly and carefully. By contrast, owner-occupiers or tenant farmers enjoyed these incentives, and therefore were willing to work long hours to maximise output. The problem of poor work incentives was especially true in southern Spain, where labour militancy and union activity increased wage costs further, as one Socialist noted in 1925:

In order to give his comrades a chance, the labourer begins late, works slowly, and tries to make his rests as frequent and long as the vigilance of the ganger will allow; as a result output falls. As he so often says, "What are we to do? If we work hard, there will be too many of us by half” (De los Ríos, 1925: 844).

Although large farmers often faced lower costs to access capital markets, this was less important in traditional agriculture because of the limited use of physical capital (Lipton, 2009: 6). Therefore economic theory suggests that where economies of scale were limited, the break-up of the large estates into small family farms would allow their new owners to use their entrepreneurial abilities to increase work opportunities and thereby raise output, efficiency, and improve income distribution.

The level of land concentration in southern Spain in the 1930s was significant, but not as great as it had been in earlier periods, or in some parts of Eastern Europe at this time ${ }^{7}$. Malefakis (1970: table 3), using the partly complete cadastre of the period, estimates that farms of over 250 hectares numbered just $0.3 \%$ of the total, but accounted for $41.2 \%$ of the total area and $27.8 \%$ of the taxable income. Some of the highest land concentration was found on the rich cereal lands of the Guadalquivir valley (Campiña), as well as the huge dehesas farms in the less populated hills and upland areas. Carrión (1975:347) believed that latifundios led to low population densities; under-cultivation; low wages; high rents; few and rickety livestock and, in general, a precarious situation over a third of the country ${ }^{8}$.

6. Carrión, El Sol, $15^{\text {th }}$ June 1919. See PAN-MonTojo (2007) for an excellent survey of Pascual Carrión's career.

7. For the size of latifundios, see Bernal (1979, 1988), López Ontiveros and Mata (1993), and CARMONA, RosÉs and Simpson (2015). In Eastern Europe, Dovring (1965: 239-57).

8. Limited evidence is actually provided as shown below. 
From the turn of the twentieth century, a growing number of urban intellectuals argued that by expropriating and giving the land to those who actually worked it, would increase output, alleviate rural poverty, and stimulate economic growth and the modernization of Spanish society 9 .

Spain on the eve of the Republic was in the process of rapid structural change, as agriculture's share of the total labour force fell from around $65 \%$ in 1910 to less than $50 \%$ in 1930, and labour productivity increased by $56 \%$ and output per hectare by $20 \%$ over the same period (Simpson, 1995a: table 1.4). However labour was slower to leave agriculture in the south, and cyclical unemployment appears to have increased significantly with the Depression. Following the 1931 elections there was a massive shift in political power away from landowners to landless labourers and small farmers as the new government passed decrees and laws which fundamentally changed rural labour and land markets ${ }^{10}$.

The Land Reform law of September 1932 promised much, with the Socialists talking of settling 100-150,000 peasants each year, although even the government's more modest goal of 60-75,000 settlers in November 1931 had been dropped by the time it was finally passed. By December 1933, two and one-halfyears after the proclamation of the Republic, only 45,000 hectares had changed hands to the benefit of just 6000 or 7000 peasants ${ }^{11}$. Historically, in countries where land reform has been successful, the state had either owned large areas of uncultivated lands or was able to confiscate properties from landowners without compensation, either because they had been politically discredited, or shown to have acquired their properties illegally (Griffin, Rahman Khan \& Ickowitz, 2002). In Spain there was very little new land that could be brought into cultivation, and expropriation without compensation of the grandees' lands following the failed Sanjurjo' military coup of 1932 provided the government with a relatively modest 1.2 or 1.3 million hectares across the country ${ }^{12}$. As the IRA was to discover, the grandees' estates offered only limited opportunities to increase farm employment, while attempts by the state to expropriate land by paying compensation was effectively halted by landowners in the law courts. The electoral victory of the centre-right led to a new and very restrictive reform bill being passed in 1935 .

In November 1932 there were major land invasions in Extremadura which resulted in the government passing an Intensification of Cultivation decree which allowed the tem-

9. For a recent survey of the literature, GonZÁlez DE Molina (2014: 23-59).

10. For a recent survey, see Robledo (2014).

11. Malefakis $(1970: 178,196)$ argues that numbers were cut for budgetary reasons.

12. MALEFAKIS (1970: 73) suggests a figure equivalent to $6 \%$ of the cultivated area. 
porary settlement of 32,821 workers on 84,836 hectares, and an average of 2.6 hectares per worker. Many of these contracts were not subsequently renewed after the 1934 harvest but even greater invasions followed the Popular Front's electoral victory in February 1936, and led to the new government settling 81,297 workers on 238,797 hectares in Extremadura (average 2.9 hectares) ${ }^{13}$. On the eve of the Civil War, Parliament was debating the expropriation of the old common lands, many of which were believed to have been sold illegally over the long nineteenth century (Beltrán, Iriarte \& Lana, 2014).

\section{TOO MANY WORKERS OR NOT ENOUGH LAND?}

Contemporaries in 1931 lacked detailed information on both the numbers that needed to be settled and the potential area of land that was available ${ }^{14}$. This was not an accident, but rather the combination of a disinterested state which until the late 1920s lacked the administrative organisation to collect basic information on land ownership and employment statistics, and strong local politicians (caciques) who had often successfully challenged the intrusion of central government in what they believed to be their areas of influence ${ }^{15}$.

The publication of Pascual Carrión's highly influential book in 1932 provided basic statistical information from the cadastre, which by this date was complete for eight of the 14 latifundio provinces (southern Spain), and well advanced in the remaining $\operatorname{six}^{16}$. For southern Spain, Carrión (1975: 362) calculated that some 5.9 million hectares were needed to settle 930,000 families ${ }^{17}$. Carrión believed that 10.4 million hectares could be made available by expropriating all the land found on estates of over 250 hectares, and assumed that half of this could be cultivated (Ibid.: table 65). In fact Carrión overestimated both the numbers of families requiring land, and the availability of land that could be cultivated (Table 1).

13. Figures are for Badajoz and Cáceres, which together accounted for $81 \%$ of those settled in 1932, and $79 \%$ in 1936. In Badajoz alone, 60,000 people occupied 3000 previously selected farms on $25^{\text {th }}$ March 1936. Boletín del Instituto de Reforma Agraria (hereafter, BIRA), September 1936, p. 357. For a discussion, see MALEFAKIS (1970: 370, 377-378) and RIESCO (2006).

14. Azaña complained about the lack of information as early as 10 th August 1931. See PAN-MoNTOJO (2005: 284-85).

15. For a general background on the question of state capacity, see especially, ScoTT (1998) and Besley and PERsSon (2011); and for Spain, Simpson and Carmona (in preparation, ch. 4).

16. It was virtually complete in Albacete, Cádiz, Ciudad Real, Córdoba, Granada, Jaén, Málaga and Toledo, and 94\% complete in Sevilla, 83\% in Badajoz, 73\% in Huelva, 67\% in Almería, 59\% in Cáceres, and $51 \%$ in Salamanca (CARRIÓN, 1975: table 3).

17. According to this study, 250,000 landless families required 10 hectares each, and a further 680,000 families with insufficient land required an additional five hectares each. 
TABLE 1

Estimates of available land and peasants to be settled in southern Spain and Badajoz

\begin{tabular}{|c|c|c|c|c|c|c|}
\hline & $\begin{array}{c}\text { Total land } \\
\text { area available } \\
\text { (ha) }\end{array}$ & $\begin{array}{c}\text { Estimated families } \\
\text { to be settled } \\
\text { '000s }\end{array}$ & $\begin{array}{c}\text { Hectares } \\
\text { per } \\
\text { family }\end{array}$ & $\begin{array}{l}\text { Estimated net output } \\
\text { per hectare } \\
\text { (pesetas) }\end{array}$ & $\begin{array}{l}\text { Output per } \\
\text { family } \\
\text { (pesetas) }\end{array}$ & $\begin{array}{l}\text { Hectares } \\
\text { required for } \\
2,000 \text { pesetas }\end{array}$ \\
\hline \multicolumn{7}{|l|}{ SOUTHERN SPAIN } \\
\hline Carrión & $5,900,000$ & 930 & 6.3 & 250 & 2500 & 8 \\
\hline Vázquez Humasqué & $3,660,000$ & 407 & 9.0 & 67 & 600 & 30 \\
\hline Robledo & $4,650,000$ & 407 & 11.4 & & & \\
\hline \multicolumn{7}{|l|}{ BADAJOZ } \\
\hline Vázquez Humasqué & 399,000 & 57 & 7 & 86 & 600 & 23 \\
\hline Simpson & $1,602,000^{*}$ & & & 171 gross & & 11.7 \\
\hline Badajoz (20 farms) ** & * $\quad 17,082$ & 2.18 & 7.8 & 102.5 & 803 & 19.5 \\
\hline
\end{tabular}

${ }^{\star}$ Refers to the whole province in 1931. ${ }^{\star \star}$ IRA plans for future settlements (see below).

Sources: Carrión (1975); El Sol, 17th May 1934; Robledo (2014); Simpson (1995b); AIRA, various boxes.

To implement the 1932 Land Reform Act, local land registries were required to provide information concerning the land that could be expropriated, and Robledo estimates that 4.65 million hectares were available from farms of more than 250 hectares (Robledo, 2010: 126-7 ${ }^{18}$. It also instructed each village to create a census of the landless workers, and poor landowners and tenants (Censo de Campesinos) ${ }^{19}$. In addition to the practical difficulties of deciding exactly which workers needed help, there were widespread complaints of abuse in compiling the Censo and many villages failed to carry it out ${ }^{20}$. Despite these short-comings, historians believe that the Censo de Campesinos gives the best indicator of the numbers of landless and poor, and was probably the source used by Vázquez Humasqué, the director of the government's IRA, in his estimate of 407,000 families needing land in $1934^{21}$.

18. Carrión's figures included all the land on the large estates, while the 1932 Land Reform allowed owners to keep a part. There were 13 different categories under which land could be expropriated, and the same piece of land could be liable for expropriation for a variety of reasons. See, MALEFAKIS (1970: ch. 8).

19. Farmers working their own land were eligible if they paid less than 50 pesetas tax, equivalent to about 10 hectares of cereal land (MALEFAKIS, 1970: 111-12; EsPINOZA et al., 2007: 310).

20. For the peasant lists, EsPINOZA et al., (2007) and CoRRIONERo (1986). There were strong incentives for local authorities, whether of the Left or Right, to create lists which rewarded their political followers.

21. Vázquez Humasqué, El Sol, $17^{\text {th }}$ May 1934. A recent estimate gives 570,000 landless adult male workers, a figure which is not too different to the 407,000 families (CARMONA, RosÉs \& SiMPSON, 2015). 
Despite the fact that Vázquez Humasqué and Carrión projected land transfers of the equivalent of between $32 \%$ and $52 \%$ of all farm land in southern Spain, there was still insufficient to allow families to be financially independent by their calculations (Table 1$)^{22}$. Carrión believed an average of 10 hectares was needed, and both authors recognized the necessity for families to supplement their incomes working elsewhere. Vázquez Humasqué argued that in the short-term, income could simply be transferred from owners to settlers, but that revenues in the long-run would need to increase from an intensification of dry-farming practices. This, he argues, depended on factors that included the development of new crops and techniques, as well as the possibilities of finding markets and remunerative prices for labour intensive crops such as maize, cotton and melons. Interestingly, Vázquez Humasqué makes no mention of the possibility of planting olive trees or vineyards, reflecting the difficulties facing these labour intensive crops in the $1930 \mathrm{~s}^{23}$.

Yet in theory sufficient land was available in southern Spain to settle most, if not all farm workers, and provide them with a subsistence income. If all the land that produced a taxable income of over 5,000 pesetas was redistributed to those employed in agriculture who earned less than this figure, then the average net income per family of this second group would increase in southern Spain from 1,922 to 2,221 pesetas (see Appendix 1 for details). In other words, confiscating the land from fewer than 13,871 owners, equivalent to $2.7 \%$ of the total farm population, and distributing it to the landless and near landless could in theory have increased their average annual incomes by $16 \%^{24}$. Agronomists at this time estimated the needs of a family farm at 5-6,000 pesetas gross a year which, deducting rent, interest on capital, and taxes (but not labour), left a net income of between 2 and 3,000 pesetas (Carrión, 1975: 361) ${ }^{25}$. As land reform did not contemplate a transfer of ownership to the settlers, rent was required to be paid.

Huge amounts of land were needed to be transferred if all families were going to have sufficient to produce even a subsistence income, and many would still have been totally dependent on the state for working capital $^{26}$. Even ignoring the fierce political opposition from landowners, a land reform of this calibre was not feasible in any country, but espe-

22. The total physical area of the 14 provinces was 18.3 million hectares, of which 11.28 million can be considered as farm land in 1931 (SIMPSON, 1995b).

23. El Sol, $17^{\text {th }}$ May 1934.

24. This figure is an upper bound, as the income and wages earned by workers and small farmers who rented plots of land from farm owners earning a taxable income of more than 5,000 pesetas a year is unknown, but should be discounted.

25. As cereals produced 500 and 600 pesetas gross per hectare, or 300 pesetas net, farms needed to be at least 10 hectares.

26. For Badajoz, see below. 
cially not in one that struggled to even measure the potential area of land available for redistribution, or the number of workers that needed to be settled. The Spanish state lacked administrative capacity and, although the number of agronomists increased from 321 to 431 between 1923 and 1934, the Italian land reform after the Second World War enjoyed an average of one technician for every 25 settlers (Pan-Montojo, 2005: 267, 274; Palerm, 1962: 26). Spreading reform over a period of several decades was theoretically possible, but seriously risked that the agenda for settlement would be set by those groups which faced the lowest costs to organize, rather than those which the government or technicians considered most in need. Indeed, there is a close correlation between the areas in southern Spain which experienced land invasions in 1932 and 1936, and those where workers were settled in greatest numbers (Carmona \& Simpson, 2016). It also helps explain why both Socialist and Anarchist syndicates demanded that the criteria for settling the land be left to their local workers' associations and not to state technicians. Given the lack of uncultivated land that the government could distribute, the fatal combination of a weak state capacity; strong legal resistance by landowners; and the legitimate demands of rural syndicates to improve members' living standards, made land reform impossible in a democratic society such as found in Spain in the $1930 \mathrm{~s}^{27}$.

\section{THE DEHESA ECONOMY AND POSSIBILITIES FOR INCREASING OUTPUT}

Even if there was insufficient land to settle all the landless, a successful land reform might be expected to improve farmers' incentives, and lead to increased output, especially as under-cultivation was believed to be common ${ }^{28}$. In Spain, land reform was attempted on two very different types of latifundios, namely the large cereal farms (cortijos), found especially in the fertile Guadalquivir river basin (Campiña), and on the dehesas, lands of poorer quality soils in upland areas of Andalucía and throughout Extremadura (Badajoz and Cáceres ${ }^{29}$. Land reform on the cortijos required asset-poor landless workers to become entrepreneurs, but on the dehesas many workers already owned draft animals and farm equipment and were experienced at organizing themselves in small groups to rent and cul-

27. For democracy and the capacity for collective action among landowners, see ALBERTUS, BRAMBOR and CENEVIVA (2016).

28. CARRIÓN $(1975: 305,361)$ believed that average output per hectare in dry farming regions could double from 300 to 600 pesetas per hectare.

29. For example, Juan Lara in April 1936, the government's agronomist for Córdoba, argued for future settlements in the province to be on the dehesas and Campiña, and not in the olive growing regions where family operations were already the norm (AIRA, Córdoba, 14, pp. 0-1). 
tivate land ${ }^{30}$. Furthermore, and unlike the Campiña, there were fewer economics of scale and no significant technological and capital barriers to intensification on the dehesas ${ }^{31}$, a fact that helps explain why they experienced most of Spain's land invasion before the Civil War. The rest of this paper looks at detail at the experience of land reform on the dehesas in Badajoz, a province which offered apparently optimal conditions for a land reform. Land ownership was heavily concentrated, with $34 \%$ of land found in farms of more than 250 hectares, and output per hectare was just 171 pesetas, or $52 \%$ the national average (Carrión, 1975: table 3; Simpson, 1994: 77) ${ }^{32}$. A total of 30 settlements were created under the 1932 Land Reform Act, which ranged in size from 1.8 to 2,855 hectares $^{33}$. The fact that all these settlements had previously belonged to grandees presents an obvious bias to our study, but it was precisely these estates belonging to absentee landowners that contemporaries believed offered the best opportunities to improve cultivation.

The large dehesas, despite the extensive nature of cultivation and low livestock densities, were complex economic organizations. The seasonal nature of the region's rainfall implied that there were abundant pastures from the autumn to the spring, but relatively little during the long summer months. This created significant fluctuations in the number of animals that could be kept during the year, and landowners often rented the whole dehesa to large livestock owners from outside the province, who removed their animals to more northerly provinces during the summer months, just as had happened for centuries with the $\mathrm{Mesta}^{34}$. These large tenants in turn sublet or sharecropped part of the land to local villagers to plant cereals and legumes (Carmona \& Simpson, 2014a; Riesco, 2006). Leases were for only two or three years, and livestock owners benefited from both the rent they received and the fact that cultivation improved pasture quality (Balabanian, 1980; Campos, 1983). The sub-tenants and sharecroppers had few legal rights, but could usually expect to receive a new plot elsewhere on the dehesa when their contracts expired. Finally, tree crops provided not just wood and charcoal, but the holm oaks fodder for pigs in the autumn, and the region was one of Europe's leading cork producers ${ }^{35}$. The diver-

30. Land reforms that provide land to the tiller rather than landless labourers have historically tended to be more successful. See, for example, Griffin, RaHMAn KHAN and ICKOwITZ (2002).

31. In particular, there was a need for deeper ploughing on the heavy, fertile soils (SUMPSI, 1978).

32. Only Albacete (165 pesetas), Cáceres (141), Huesca (163) and Teruel (114) had lower figures.

33. Numbers are imprecise because land reform in some cases joined neighbouring estates, and divided others (see Appendix 2). Another three communities, Montelobo, Mariana, and Nava, had existed since 1924 (AIRA, Monografías, box 6.7).

34. The Jurados Mixtos de la Propiedad de Cáceres specifically name the provinces of León, Ávila and Segovia.

35. The charcoal industry employed between 15 and 20,000 families part-time, essentially for the national market, but output had dropped significantly from the First World War (RosiQUE, 1988: 57, 70). 
sity of the dehesa can be seen from the agronomists' plans to settle six estates in the 1930s (Table 2).

TABLE 2

Estimates for future income on six settlements in Badajoz (\%)

\begin{tabular}{lcccc}
\hline & Arable & Livestock & Tree crops & Total \\
\hline Año y vez without pastures & & & & \\
\hline Las Cabras & 82.7 & 10.1 & 7.2 & 100 \\
Merinillas & 96.1 & 3.9 & 0.0 & 100 \\
\hline Dehesas with pastures & & & & \\
\hline Margaritas & 50.8 & 34.6 & 14.6 & 100 \\
La Pulgosa & 35.2 & 49.5 & 15.4 & 100 \\
Tablado y Capilla & 77.1 & 22.0 & 1.0 & 100 \\
El Zarzoso & 45.0 & 47.6 & 7.4 & 100 \\
\hline Average settlements (\%) & $\mathbf{6 8 . 0}$ & $\mathbf{2 5 . 4}$ & $\mathbf{6 . 6}$ & $\mathbf{1 0 0}$ \\
\hline Sources:AIA, La
\end{tabular}

Sources: AIRA, La Pulgosa, box 6.37; Merinillas Altas, box 6.59; Las Cabras, box 6.24; Las Margaritas, box 6.9; Zarzoso, box 6.42.

The intensity of cultivation depended on soil fertility, farm-gate prices, and the distance that workers had to travel from their villages to reach the fields. In Badajoz between 1910 and 1930, the growing use of artificial fertilizers and high cereal prices led to the area of cereals and legumes increasing $68 \%$, from 258,000 to 434,000 hectares, although it is impossible to determine to what extent this took place on the dehesas as oppose to the richer soils of the interior such as the Tierra de Barros (Zapata, 1986: 1413-16). There is, however, some evidence to suggest that high wheat prices had led to rotations being dangerously shortened on the dehesas before the Second Republic (Carmona \& Simpson, 2016). At the same time, the total live weight of animals increased by $60 \%$ between 1905/10 and 1929/33, increasing demand for pasture and fodder (Zapata, 1986: table 3.12).

Population density in Badajoz was just 32.3 per square kilometre, even including the provincial capital. Agriculture employment was highly seasonal, so most workers lived in large villages to be close to information concerning work opportunities in both the formal and informal sectors ${ }^{36}$. For the 28 settlements for which information is available, only three were found within a kilometre of the nearest village, but 17 (or $61 \%$ of the total) were five kilometres or more, discouraging intensive cultivation. In 1932 the state had vir-

36. Wheat cultivation required just 16.2 work days per hectare on the dehesas, and the preparation of the fallow a further seven days (INSTITUTO DE REFORMA AGRARIA, 1934: 89). 
tually no information on how farms were actually being cultivated, or the potential to increase output without exhausting the soil. Carrión surprising gives only one example of a poorly cultivated farm in his book. This was a 444 hectare dehesa in Trujillo (Cáceres), where $20 \%$ of the land was under permanent pasture, $40 \%$ lay in unsown fallow, $20 \%$ ploughed fallow, and just $20 \%$ sown with wheat, barley, and oats. Yields and livestock densities were low, and gross output was 116 pesetas per hectare, or 37 pesetas net. Carrión (1975: 328-32) suggested that these figures were similar over much of Badajoz, and argued that there was significant potential for increasing output and employment through a shortening of the fallow (Table 3$)^{37}$. However, he offers virtually no information concerning ecological restrictions, farm gate prices, or the practical problems associated with settling large numbers of workers at a significant distance from their homes ${ }^{38}$.

\section{TABLE 3}

\section{Output and input in cereal and legume production in Andalusia and Extremadura} (in pesetas per hectare and year) $^{39}$

\begin{tabular}{lcccccccr}
\hline & OUTPUT & $\begin{array}{c}\text { Seeds and } \\
\text { fertilizers }\end{array}$ & $\begin{array}{c}\text { Work } \\
\text { animals }\end{array}$ & $\begin{array}{c}\text { Interest, } \\
\text { insurance }\end{array}$ & $\begin{array}{c}\text { Total } \\
\text { inputs }\end{array}$ & $\begin{array}{c}\text { Inputs/ } \\
\text { output (\%) }\end{array}$ & $\begin{array}{r}\text { Ricardian } \\
\text { rent }\end{array}$ & Labour \\
\hline Cereal año y vez & 350 & 60 & 50 & 20 & 130 & $37 \%$ & 120 & 100 \\
Al tercio & 225 & 35 & 30 & 15 & 80 & $36 \%$ & 75 & 70 \\
Al cuarto & 160 & 25 & 20 & 12 & 57 & $36 \%$ & 53 & 50 \\
Al quinto & 98 & 20 & 15 & 8 & 43 & $44 \%$ & 20 & 35 \\
Trujillo farm & $\mathbf{1 1 6}$ & $\mathbf{2 0}$ & $\mathbf{2 5}$ & $\mathbf{4 . 5}$ & $\mathbf{4 9 . 5}$ & $\mathbf{4 3 \%}$ & $\mathbf{1 7}$ & $\mathbf{2 9 . 2}$ \\
BADAJ0Z* $^{*}$ & 123 & NA & NA & NA & NA & NA & 38 & NA \\
\hline
\end{tabular}

${ }^{\star}$ Cereal and legumes; 1930-35 area cultivated (GEHR, 1983a); 1931 production (Simpson, 1995b). The value has been multiplied by 1.22 to compensate the poor harvest of 1931 , which was $82 \%$ of the average wheat harvest for 1930-35.

Sources: based on cadastral records, in Carrión (1975: 324).

Following the 1932 Land Reform Act, agronomists began to draw up plans for new settlements (planes de asentamiento) on the confiscated estates, and reported on how the farms were currently being run and made proposals for improvements and projected fu-

37. Arable accounted for $78 \%$ of income. A second dehesa is also described, but it raised only sheep, goats and pigs.

38. Vázquez Humasqué believed in 1931 that all workers, every one of them, were able to run a farm and therefore the agrarian problem could be solved by dividing the estates and giving labourers work tools. Cited in RobLedo (2007: 107).

39. The cadastral rent was a fiscal estimate, essentially equivalent to the Ricardian rent, and did not necessarily match the market rent. 
ture income $\mathrm{e}^{40}$. For the 20 projects that can be used for Badajoz, seven corresponded to estates that planned to use año y vez rotations, where half the land was planted with cereals, and the other half left fallow; another seven where cereals were planted once every three years (al tercio); and finally on the remaining six, cultivation was even more extensive. Interestingly, this implied that the agronomists proposed very few changes in the rotations, and about half their reports contained no suggestions for improvements at all ${ }^{41}$. Their criticism of previous practices in general was limited to the insufficient use of fertilizers (but in only two cases); the presence of grama grass suggesting poor cultivation (again, two cases); the planting oats on the stubble (four cases) ${ }^{42}$; or the lack of legumes being sown in the fallow, even though this was already being done on 13 out of the 20 farms ${ }^{43}$. They made no proposals to plant new crops such as maize or cotton or increase livestock density ${ }^{44}$. The overall picture from these 20 farms is that agronomists believed that only minimal changes could be introduced, at least in the short term. One possible explanation for this lack of change is that the agronomists were often making plans for farms that had already seen an increase in the area cultivated following the 1932 Intensificación de cultivos decree, as in Badajoz some 53,146 hectares, the equivalent to a tenth of the total area sown, had been given to workers to cultivate for two years in small plots ${ }^{45}$. However, according to Vázquez Humasqué, this land simply compensated for that which landowners had failed to cultivate in their protests against the Republic, leaving the total area unchanged ${ }^{46}$.

40. Information was required to determine the number of workers who could be settled, as well as the compensation that had to be paid to the previous owners for the standing crops, work animals, and farm equipment. The planes de asentamiento were perhaps the first attempt by a Spanish government to systematically collect farm level information. For a description, see LóPEz ONTIVEROS and MATA (1993: ch. 5).

41. Six agronomists who signed for 19 settlements can be identified: Benjamín Escola Diego (9 settlements); Julio Alonso (6); Francisco Corral (1); Bonifacio Torralba (1); Delgado Moral (1) and Manuel Jiménez (1).

42. This, the resiembra or relva, was highly criticised by agronomists despite the use of chemical fertilizers.

43. By contrast, on a farm in Trujillo, very close to Carrión's example, the IRA's agronomist proposed to reduce the intensity of planting from once every three to once every four years, as the soil was becoming exhausted (AIRA, box 10.0.01).

44. The agronomist noted for the Señorío y Taldarroba estate that the introduction of cotton or maize would require constant supervision by technicians and was impractical in the short-run given their current workloads (AIRA, box 6.37, p. VII).

45. BIRA, October 1933, pp. 52-60, MALEFAKIs (1970: 236-43) and GEHR (1983b: 308). Workers were given on average a fifth of the farm area.

46. BIRA, March 1933, p. 261. 


\section{TABLE 4}

Agronomists' proposals for cereals on 20 settlements in Badajoz (pesetas per hectare)

\begin{tabular}{|c|c|c|c|c|c|c|c|c|c|}
\hline \multicolumn{10}{|c|}{ INPUT } \\
\hline \multicolumn{2}{|c|}{ Settlements } & \multirow{2}{*}{$\begin{array}{c}\begin{array}{c}\text { Wheat } \\
\text { yields (1) }\end{array} \\
13.4\end{array}$} & \multirow{2}{*}{$\begin{array}{c}\text { OUTPUT } \\
\text { (2) }\end{array}$} & \multirow{2}{*}{$\begin{array}{c}\text { Seeds and } \\
\text { fertilizers }\end{array}$} & \multirow{2}{*}{$\begin{array}{c}\begin{array}{c}\text { Working } \\
\text { animals }\end{array} \\
51\end{array}$} & \multirow{2}{*}{$\begin{array}{c}\begin{array}{c}\text { Interest, } \\
\text { insurance }\end{array} \\
22\end{array}$} & \multirow{2}{*}{$\begin{array}{c}\begin{array}{c}\text { Total } \\
\text { inputs }\end{array} \\
134\end{array}$} & $\begin{array}{c}\text { Inputs } \\
\text { /output(\%) }\end{array}$ & $\begin{array}{c}\text { Cadastral } \\
\text { rent }\end{array}$ \\
\hline Cereal año y vez & 7 & & & & & & & $33 \%$ & 43.6 \\
\hline Al tercio & 7 & 11.8 & 216 & 31 & 33 & 10 & 74 & $35 \%$ & 40 \\
\hline Al cuarto & 3 & 10.0 & 168 & 23 & 23 & 8 & 55 & $33 \%$ & 37 \\
\hline Al quinto y con pastos & 3 & 7.3 & 122 & 13 & 14 & 4 & 30 & $25 \%$ & 34 \\
\hline Average 20 settlements & 20 & 11.4 & 263 & 38.0 & 35.0 & 13.0 & 85.0 & $32 \%$ & 40.0 \\
\hline BADAJOZ $(1930-35)^{\star}$ & - & 9.5 & 123 & NA & NA & NA & NA & NA & 38.0 \\
\hline
\end{tabular}

(1) In quintals per hectare sown; (2) refers to cereals and legumes cultivated. Rotations in the IRA settlements refer only to the area cultivated.

${ }^{\star}$ Average for the whole province.

Sources: AIRA, Badajoz, various boxes; and Table 3, last line "Badajoz".

Yet although agronomists recommended few changes, they projected future wheat yields $20 \%$ greater on average and output per hectare $114 \%$ higher than the provincial averages, despite the fact that land quality according to the cadastre was only $5 \%$ better (Table 4). On the "best" seven estates, cereal output was planned to be over 400 pesetas per hectare on land of only fourth or fifth quality ${ }^{47}$. Therefore agronomists predicted higher levels of output with minimum changes in production methods to be achieved on relatively poor soils. The source of error is not easy to identify. One explanation is that agronomists simply extrapolated the yields found on the best lands to those poorer soils of the farm. For example, the agronomist proposed año y vez rotations for the Castillo de Guadajira estate, but sufficiently fertile soils were found on only a sixth of the farm ${ }^{48}$. On the 596

47. Cereal production of 350 pesetas per hectare per year corresponded to a cadastral rent of 120 pesetas, while the figure for the settlements on which agronomists planned a production of over 400 pesetas had cadastral rents of between 25 pesetas (Represa) and 82 pesetas per hectare (Fuente Omendo). Fuente Omendo, for example, was a farm of 300 hectares that was projected to produce 600 pesetas per hectare under dry farming, despite producing only traditional products such wheat, barley, rye and legumes. Livestock products are excluded.

48. The cadastral figure for the farm ( 36 pesetas per hectare) was the average of very different soil qualities: on the best (in reality only second class) the figure was 63 pesetas per hectare and represented $17 \%$ of the total estate; $40 \%$ were third and fourth class (between 40 and 48 pesetas); and 30\% between fifth and seventh (16-30 pesetas), which explains why before being expropriated only a third of the fallow was sown. 
hectare Merinillas estate, año y vez was already practiced (wheat or barley, followed by chickpeas and beans) before expropriation, but the agronomist now proposed eliminating the barley (despite yields of 1.8 tonnes per hectare), and extending the same rotation to the 120 hectares of pasture by increasing the use of superphosphates to 300 kilos per hectare ${ }^{49}$. In fact production in the first year was very mediocre, with wheat yields of only 0.75 tonnes against an expected 1.75 to 2.20 tonnes $^{50}$. Another possibility is that the cadastral rent contains errors. There is no evidence that this is the case, although the continued strength of vertical clientelistic networks perhaps should not rule out this possibility for some farms ${ }^{51}$.

Finally, although the extensive cultivation techniques found in Badajoz in the early 1930s were more a consequence of natural resource endowments and farm prices than supposed inefficiencies caused by absentee landowners, it is possible that a land reform, by increasing significantly the amount of labour used, could compensate in some way for the poor quality soils. In fact, as we shall consider now, work incentives remained poor and there is no evidence that significantly higher yields were possible.

\section{THE EXPERIENCE OF LAND REFORM IN BADAJOZ}

Successful land reforms, such as undertaken in Japan or Taiwan following the Second World War, led to tenants receiving full property rights to the land, thereby increasing both their ability to access credit markets and providing incentives to cultivate it more efficiently (Griffin, Rahman Khan \& Ickowitz, 2002). This did not happen in Spain. Instead, landless workers became tenants of the IRA, and consequently were unable to sell or mortgage the land. Despite this problem, the fact that workers were guaranteed continuous access to the land might still have led to greater output. However, to succeed, three major collective action problems traditionally associated with community arrangements needed to be resolved: the threat of exit by high-ability members; adverse selection (the attraction of low-ability members); and shirking (Abramitzky, 2011). The evidence suggests that these problems were significant in Badajoz, and the IRA was required to intervene extensively for settlements to remain viable.

49. This pasture had been previously given to 122 senareros to cultivate (AIRA, box 6.59, pp. II-IV). 50. In Badajoz, wheat yields fell from 1.3 to 0.78 tonnes or $40 \%$ between 1934 and 1935 (GEHR, 1991: 226, 230).

51. Major changes in farm prices cannot be the cause as the cadastral in Badajoz was carried out after the First World War. 
TABLE 5

Statistical description of the 30 Badajoz Settlements (1934-36)

\begin{tabular}{|c|c|c|c|c|c|c|}
\hline & \multicolumn{5}{|c|}{ Settlements (4) } & \multirow[b]{2}{*}{ Median } \\
\hline & $\begin{array}{c}\text { Province of } \\
\text { Badajoz (1930) }\end{array}$ & 30 Settlements & Minimum & Maximum & Average & \\
\hline Area in hectares & $1,664,047$ & 17,082 & 1.8 & 2,855 & 632 & 437 \\
\hline \multicolumn{2}{|l|}{ Permanent pasture and forest } & 1,882 & 0 & 305 & 70 & 33 \\
\hline \multicolumn{2}{|l|}{ Total $(\%)$} & $11 \%$ & $0 \%$ & $60 \%$ & $14 \%$ & $7 \%$ \\
\hline Total output* (in pesetas) (1) & $274,278,000$ & $3,472,600$ & 750 & 460,000 & 128,600 & 75,610 \\
\hline Per hectare* & 165 & 203.3 & 92 & 497 & 234 & 174 \\
\hline Livestock and cork share of total outpu & $35 \%$ & $8 \%$ & $0 \%$ & $66 \%$ & $18 \%$ & $15 \%$ \\
\hline \multicolumn{6}{|l|}{ and rent ${ }^{\star}$} & 33,500 \\
\hline Per hectare & 114.9 & 102.5 & 44 & 347 & 120.4 & 91.8 \\
\hline Net income (cadastral assessment) (2) & $83,000,000$ & 730,280 & 267 & 120,000 & 27,047 & 19,100 \\
\hline Per hectare & 49.9 & 42.8 & 31.3 & 256.3 & 49 & 41 \\
\hline \multicolumn{7}{|l|}{ SETTLERS } \\
\hline Number of settlers/families (3) & 105,337 & 2,180 & 2 & 560 & 81 & 32 \\
\hline Hectares per settler & 15.8 & 7.8 & 0.9 & 44.1 & 13.9 & 12.8 \\
\hline Output per settler (net of inputs but with ren & $n t s)^{*} 2,604$ & 1,593 & 195 & 3,512 & 1,827 & 1,714 \\
\hline Output per settler excluded rents* & 1,816 & 803 & 145 & 3,029 & 1,315 & 1,212 \\
\hline Hectares needed per settler to get a net & & 19.5 & 5.7 & 45.5 & 26.5 & 21.8 \\
\hline \multicolumn{7}{|l|}{ Income of 2,000 pesetas* } \\
\hline Hectares needed per settler to get & & 12.7 & 3.7 & 29.5 & 17.2 & 14.2 \\
\hline a net income of 1,300 pesetas* & & & & & & \\
\hline
\end{tabular}

(1) Net of seed.

(2) Badajoz adjusted.

(3) Badajoz figures in Carrión (1932).

(4) Minimum, maximum, average and median within the 30/22 (when indicated) settlements figures. *22 settlements.

Sources: AIRA, 22 boxes; Badajoz: Simpson (1995b) and Carrión (1975).

A major decision facing the government was the number of families to be settled on each farm. Manuel Azaña, the Prime Minister, rejected a carefully prepared proposal by the Ministry of Agriculture to provide land and a government loan of 12,000 pesetas apiece, 
equivalent to a subsistence income for six years, to 4,000 families $^{52}$. A similar fate met the plan to settle 23 workers, each with their own plough team and producing a gross income of 7,589 pesetas per family, on the 596 hectare Merinillas Altas estate in Badajoz. These projects, that converted a relatively small number of asset-poor labourers into prosperous family farmers, failed to solve the severe regional unemployment, and were therefore considered politically unacceptable. Instead, land was assigned to cover a family's basic needs, leaving them dependent on labour markets for seasonal employment. On Merinillas Altas, instead of the recommended 23 families, 119 were settled, each with five hectares producing an estimated net income of 1,467 pesetas (2,346 pesetas gross).

In a few cases existing independent associations were allowed to work the confiscated estates $^{53}$. In Zahinos, the local syndicate El Progreso claimed to have cultivated Las Cabras since 1908, and was allowed to continue ${ }^{54}$. Likewise in Higuera de Vargas, where all the villagers belonged to the La Benéfica association, a total of 560 individuals, or a quarter of its membership, were permitted to stay on Ramira Alta which they had rented since 1928, each with less than two hectares ${ }^{55}$. In Torremejía, two distinct associations in May 1936 were authorized to cultivate Señorío y Taldarrobas: the socialist syndicate with 180 members were given 340 hectares and the second, possibly Catholic, syndicate, given 960 hectares for its 65 members. The fact that Torremejía's population was 1,200 suggests that a member in each agricultural household belonged to one association or the other. For the associations, although average plots did not exceed five hectares, they helped alleviate unemployment, while for the IRA it had the advantage that the settlers possessed their own farm equipment ${ }^{56}$. However, it also permitted some individuals access to land who otherwise would have failed to meet the selection criteria of the Censo de Campesinos. Furthermore, the associations were now expected to follow rules imposed by the IRA, rather than their own informal norms on how farm operations should be carried out and by whom, and their members were collectively responsible for all debts.

In Badajoz, the number of settlers was almost double than initially recommended by the agronomists, either because land was rented to local associations, or because of the

52. $6^{\text {th }}$ July 1933, in AzAÑA (1997: 383). He complained that loans were given for everything, from a pair of mules to two water jars for each settler. The farm was probably in Andalusia.

53. Article 12c of the 1932 Land Reform Law gave preference to collective cultivators for settlement on uncultivated land (MALEFAKIS, 1970: 229). For workers' organizations in Extremadura, SÁNCHEZ MARROYO (1990).

54. AIRA, box 6.24.

55. The association had 2,209 members and cultivated a number of farms. Letter dated $19^{\text {th }}$ May 1934. AIRA, box 6.38 .

56. Settlers on Señorío y Taldarrobas already possessed work animals (AIRA, box 6.37). 
political demands to maximise numbers ${ }^{57}$. The estimated net family income on each farm ranged from 145 on Ramira Alta to 3,029 on Represa, with an average of 1,315 pesetas (Table 5). If, as suggested above, agronomists sometimes exaggerated the farm's production potential, the real figures would be lower still. A combination of large families and small plots implied that workers were forced to seek off-farm employment making it hard to monitor their effort on the settlements, and leading to complaints about workers' underperforming or simply disappearing from them ${ }^{58}$. For example, on Ramira Alta, 153 settlers were expelled for absenteeism, while another 53 were fined for not working their plots adequately ${ }^{59}$.

Except for the tenant associations, individual settlers were usually chosen from the nearest village according to a rough indicator of economic need, with the Acción Social selecting household heads with the greatest number of individuals over 12 years in their care from the Censo de Campesinos ${ }^{60}$, resulting in an average age of almost fifty (Table 6). In 1930, male illiteracy in Badajoz was $40 \%$, but figures could vary significantly in neighbouring villages ${ }^{61}$. There were also important differences between the new settlements, with no workers being able to sign their names on the Zarzoso estate, but $72 \%$ on La Pulgosa ${ }^{62}$. The fact that the numbers of those receiving land who could sign their names were sometimes higher than literacy rates in the local village, and that some settlers owned work animals, farm tools, or small plots of land, suggests that it was not always the poorest peasants who were selected ${ }^{63}$.

57. The figure is reduced to $14 \%$ if Cabra Alta and Baja and Ramira Alta are excluded.

58. On La Pulgosa, for example, Román Pérez in December 1938 simply disappeared to look after his sheep and goats, while Francisco Rodríguez wanted to leave to dedicate time to his own land. Other members also had abandoned their plots, but in these cases it was probably for political, rather than economic, reasons (AIRA, box 6.66). See also for Egido Nuevo (box 10.36) and divisions among settlers on Matadero (box 10.6). See also, CARMONA and SimpSOn (2015).

59. AIRA, box 6.38. Following the tragic events after $18^{\text {th }}$ July 1936, which saw Franco's troops rapidly sweep across large areas of Extremadura, some workers fled the newly created settlements, and others were evicted or shot. In Badajoz in 1938, only 1,221 of the original 2,040 workers remained, with 350 having rejected the opportunity to join the farms, 145 "disappearing", and 33 being expelled.

60. Some settlements also recruited specialist workers, such as shepherds to tend the village flock. The 1932 Land Reform Act (Base 11) gave preference to cultivators with families, and within this category, those with most children. Most communities were established after the 1933 elections.

61. The gender gap was very large, and total illiteracy reached almost two-thirds for the province (INSTITUTO DE REFORMA AgRARIA, 1934: 110).

62. Information is available for most settlements, but it is sometimes difficult to be sure who was signing the documents.

63. In the case of La Pulgosa, not only could $72 \%$ sign their name, but all had some work animals (AIRA, box 6.37). 
TABLE 6

Demographic features of six farm settlements

\begin{tabular}{lccccccc}
\hline & $\begin{array}{c}\text { Households } \\
\text { number }\end{array}$ & $\begin{array}{c}\text { Average age } \\
\text { of the household } \\
\text { head }\end{array}$ & $\begin{array}{c}\text { Total } \\
\text { households } \\
\text { members }\end{array}$ & $\begin{array}{c}\text { Children } \\
\text { older than } \\
\text { 14 years }\end{array}$ & $\begin{array}{c}\text { Average } \\
\text { per } \\
\text { household }\end{array}$ & $\begin{array}{c}\text { Settlers } \\
\text { literacy } \\
\text { rate }\end{array}$ & $\begin{array}{c}\text { Male literacy } \\
\text { in the same } \\
\text { village }\end{array}$ \\
\hline La Pulgosa & 39 & 56.0 & 289 & 181 & 4.6 & 72 & 57 \\
Tablado y Capilla & 17 & 42.6 & & 16 & 0.9 & & \\
El Zarzoso & 14 & 50.2 & & 36 & 2.6 & 0 & 17 \\
Naveperas & 31 & 50.5 & 180 & 44 & 1.4 & 45 & 57 \\
Merinillas Altas & 61 & 51.4 & 388 & 83 & 1.4 & 41 & 69 \\
Quinto de Almadén & 33 & 44.8 & 166 & 35 & 1.1 & 54 & 52 \\
\hline Total & $\mathbf{1 9 5}$ & $\mathbf{4 9 . 3}$ & & $\mathbf{3 9 5}$ & $\mathbf{2 . 7}$ & & \\
\hline
\end{tabular}

Sources: AIRA, La Pulgosa, box 6.66; Tablado y Capilla, box 6.40; El Zarzoso, box 6.42 bis; Naveperas, box 6.36; Merinillas Altas, box 6.59; Quinto de Almadén, box 6.38; Dirección General del Instituto Geográfico, Catastral y de Estadística (1932).

Many agronomists and labour syndicates argued that it was preferable to maintain the estates and work them as collectives, suggesting that they believed there were some economies of scale. Settlers by contrast, perhaps aware of the potential difficulties of working in groups containing an average of 81 families, preferred to work the land individu$a^{a l l y}{ }^{64}$. The result was a hybrid situation whereby each family cultivated their own land on the open fields, but the organization of the village flock, the payment of rent, and the responsibility for repaying capital was a communal responsibility ${ }^{65}$. The nature of agency problems and transaction costs were changed rather than reduced, and the possibilities of increasing output through labour intensive improvements limited to extending the area of subsistence cereals and collecting wood for charcoal production.

The IRA advanced capital to at least 25 of the 29 settlements to purchase farm machinery, and to 22 to buy work animals, equivalent to $37 \%$ of all the loans made, with the rest being used to purchase livestock, especially sheep and pigs ${ }^{66}$. In addition, on all but two farms, the IRA advanced personal loans to settlers for seed corn and fertilizers, and to feed their families and work animals until the harvest, an important function that

\section{Figures refer to Badajoz (AIRA, box 6.7).}

65. It was believed that workers would sell the land if they were given full possession. Following the 1935 Land Reform, the rent was paid to the old landowners. Sales were made collectively and any surplus distributed among settlers after rent and credit repayments had been made to the IRA. This differed to the Intensificación de cultivos, where settlers were individually responsible for rental payments. As the old cadastral rents were always much lower, this helped inflate production and could therefore justify a greater number of settlers.

66. Calculated from AIRA, box 6.7. 
landowners had often previously performed (Table 8). However, on the projected settlements, capital inputs remained low ${ }^{67}$. Neither the state nor settlers had experience in managing credit operations, increasing the confusion already caused by the fact that the settlement solicited the loan, but responsibly for the debt was individual ${ }^{68}$. As a result land reform, rather than creating a network of small independent family farms, simply changed workers' dependence on private landowners for the IRA. The fact that the foreman kept daily accounts of the work carried out by each settler, reinforced the idea that they were wage labourers rather than independent farmers and in one case, in the province of Cádiz, workers actually went on strike for more pay (Macarro, 2000: 233).

\section{TABLE 7}

\section{Estimated income per settler in Badajoz, 1935}

\begin{tabular}{|c|c|c|c|c|c|c|c|}
\hline & $\begin{array}{l}\text { Cultivated } \\
\text { area } \\
\text { (ha) }\end{array}$ & $\begin{array}{l}\text { Projected total yearly } \\
\text { income according to } \\
\text { agronomists (pesetas) }\end{array}$ & $\begin{array}{l}\text { Number } \\
\text { of } \\
\text { yuntas }\end{array}$ & $\begin{array}{l}\text { Number } \\
\text { of } \\
\text { settlers }\end{array}$ & $\begin{array}{l}\text { Cultivated } \\
\text { area per } \\
\text { settler (ha) }\end{array}$ & $\begin{array}{c}\text { Projected total } \\
\text { income per settler } \\
\text { (pesetas) grosssettler }\end{array}$ & $\begin{array}{l}\text { Projected total } \\
\text { income per } \\
\text { (pesetas) net }\end{array}$ \\
\hline \multicolumn{8}{|c|}{ NUMBER OF SETTLERS IN THE ORIGINAL PROJECT } \\
\hline La Pulgosa & 680 & 90,657 & 7 & 28 & 24.3 & 3,238 & 988 \\
\hline Merinillas Altas & 596 & 279,155 & 23 & 23 & 25.9 & 12,137 & 7,599 \\
\hline $\begin{array}{l}\text { Las Cabras } \\
\text { (Baja and Alta) }\end{array}$ & 2,581 & 537,590 & 58 & 235 & 11.0 & 2,288 & 1,202 \\
\hline Las Margaritas & 430 & 66,124 & 5 & 32 & 13.4 & 2,066 & 914 \\
\hline Zarzoso & 193 & 37,595 & 2 & 14 & 13.8 & 2,685 & 667 \\
\hline $\begin{array}{l}\text { Señorío } \\
\text { y Taldarrobas }\end{array}$ & 2,855 & 612,408 & 50 & 250 & 11.4 & 2,450 & 1,431 \\
\hline Ramira Alta & 982 & 166,012 & 18 & 560 & 1.8 & 296 & 143 \\
\hline $\begin{array}{l}28 \text { settlements } \\
\text { total }\end{array}$ & 12,904 & n. a. & & 1,172 & 11.0 & n. a. & \\
\hline \multicolumn{8}{|c|}{ FINAL NUMBER OF SETTLERS (WHEN MODIFIED) } \\
\hline La Pulgosa & 680 & 90,657 & & 39 & 17.4 & 2,325 & 709 \\
\hline Merinillas Altas & 596 & 279,155 & & 119 & 5.0 & 2,346 & 1,466 \\
\hline $\begin{array}{l}\text { Las Cabras } \\
\text { (Baja and Alta) }\end{array}$ & 2,581 & 537,590 & & 527 & 4.9 & 1,020 & 536 \\
\hline $\begin{array}{l}28 \text { settlements } \\
\text { total }\end{array}$ & 12,904 & n. a. & & 1,941 & 6.6 & n. a. & n. a. \\
\hline
\end{tabular}

Sources: AIRA, La Pulgosa, box 6.37; Merinillas Altas, box 6.59; Las Cabras, box 6.24; Las Margaritas, box 6.9; Zarzoso, box 6.42 .

67. On Represa, Santisfolla or Merinillas, capital inputs were lower than $30 \%$ of net output, compared to the $37 \%$ used in the cadastral.

68. For the Spanish government's lack of experience with rural banks, see CARMONA and SIMPSON (2014b). 
TABLE 8

Loans advances by the IRA to settlers (1934-36) (in current pesetas)

\begin{tabular}{|c|c|c|c|c|c|c|c|}
\hline & \multicolumn{7}{|c|}{ Institutional Ioans (1933-36) } \\
\hline & \multicolumn{2}{|c|}{ FIXED CAPITAL } & \multicolumn{5}{|c|}{ WORKING CAPITAL } \\
\hline & Machinery & Livestock & $\begin{array}{l}\text { Seeds and } \\
\text { fertilizers }\end{array}$ & $\begin{array}{l}\text { To feed } \\
\text { settlers }\end{array}$ & $\begin{array}{l}\text { To feed } \\
\text { animals }\end{array}$ & Others & $\begin{array}{l}\text { Total } \\
\text { loans }\end{array}$ \\
\hline TOTAL 28 SETTLEMENTS & 160,110 & 829,702 & 390,752 & 450,422 & 319,514 & 176,997 & $2,327,497$ \\
\hline$(\%)$ & 6.9 & 35.6 & 16.8 & 19.4 & 13.7 & 7.6 & 100 \\
\hline \multicolumn{8}{|l|}{ FOUR LARGEST LOANS } \\
\hline Las Cabras (Alta and Baja) & 0 & 199,378 & 74,635 & 0 & 14,000 & 44,127 & 332,140 \\
\hline$(\%)$ & 0 & 60.0 & 22.5 & 0 & 4.2 & 13.3 & 100.0 \\
\hline La Pulgosa & 0 & 81,623 & 20,190 & 60,200 & 8,879 & 5,145 & 176,037 \\
\hline$(\%)$ & 0 & 46.4 & 11.5 & 34.2 & 5.0 & 2.9 & 100.0 \\
\hline Merinillas Altas & 20,808 & 17,843 & 40,901 & 38,700 & 23,864 & 4,708 & 146,824 \\
\hline$(\%)$ & 14.2 & 12.2 & 27.9 & 26.4 & 16.3 & 3.2 & 100.0 \\
\hline Margaritas & 5,050 & 67,000 & 6,519 & 7,828 & 22,862 & 14,420 & 123,679 \\
\hline$(\%)$ & 4.1 & 54.2 & 5.3 & 6.3 & 18.5 & 11.7 & 100.0 \\
\hline Per household (28 settlements) & 214 & 954 & 342 & 527 & 425 & 207 & 2,669 \\
\hline Maximum (Zarzoso) & 80 & 2,750 & 368 & 619 & 1,110 & 570 & 5,497 \\
\hline Minimum (Ramira Alta) & 0 & 71 & 56 & 33 & 3 & 3 & 166 \\
\hline
\end{tabular}

Señorío y Taldarrobas is excluded as it received none of the loans that it was granted in 1936.

Sources: monografías de las 33 comunidades de Badajoz, AIRA, box 6.7, 1938. See Appendix 2.

The theoretical literature suggests that a successful land reform increases output because family-run farms have good incentives to work quickly and diligently, both crucial factors in the time-constrained activities found in agriculture. However, economic development in Spain by the 1930s perhaps had reached a level where there was no longer a clear inverse-relationship between farm size and land productivity, and capital requirements was becoming increasingly important (Lipton, 2009: 65) ${ }^{69}$. With cereals, it was not clear how significantly greater output could be obtained using just higher labour inputs, and the important economics of scale found on the latifundios is reflected in the recommendations of both agronomists and syndicates to maintain the organizational structure on the confiscated estates. Intensive livestock farming was also theoretically possible on marginal cereal land and dehesas, but this required costly feed-inputs, as well as higher farm prices and a significantly better marketing organization than was available in the 1930s if it was to be profitable.

69. The relationship still existed with specialised tree crops and irrigation, but not with cereals and extensive livestock farming. 
The dehesas provided pasture for large numbers of animals during the winter months, that traditionally were rented, and some enjoyed a substantial income from cork. However, in both cases significant difficulties existed if the new settlements were going to integrate these activities within the community to reduce the levels of underemployed among their workers, rather than sub-contracting them to third parties, the preferred option of the IRA because of the greater security of payment ${ }^{70}$. The poor soils found on many dehesas implied that labour-intensive cereals were never going to significantly increase living standards, and cereal and legume production on the settlements were often small scale, and sufficient for little more than household needs.

Spain by the 1930s was perhaps too rich for a "classic" land reform, and while the settling of large numbers of asset-poor workers helped redistribute incomes, it failed to increase either land or labour productivity. Land reform might have had a better chance of success if independent farms had been created with an annual turnover of around 7,500 pesetas as originally suggested by the IRA, but perhaps only a third of the poor would have benefitted, making the project not just excessively expensive but also politically unacceptable to those that were excluded. Instead, limiting reform to providing emergency relief for landless workers for one or two years, increased output in the short run, but ran the risk of exhausting soil fertility and the basis for future growth.

\section{CONCLUSION: THE OBSTACLES TO LAND REFORM IN SPAIN}

A land reform such as the World Bank might propose today, which created large numbers of small, independent farms that gave their owners strong incentives to raise production, was not feasible over much of southern Spain in the 1930s, because there was not enough suitable land to redistribute. This article suggests that many contemporaries were wrong, not just in their assumptions that extensive areas of uncultivated land existed that could be easily brought into cultivation, but also that absentee owners systematically cultivated badly their estates. The information Extremadura's dehesas contained in the IRA archives clearly shows that there were limited possibilities for significantly increasing output in the short term.

The deep economic crisis in the 1930s reversed the flow of migrant labour, and resulted in large numbers of workers returning to their villages rather than leaving for better paid city employment, making the realization of land reform even harder. With a grow-

70. Therefore on La Pulgosa, the harvesting of cork, a skilled task, continued to be carried out by outsiders (CARMONA \& SIMPSON, 2015). 
ing demand but limited supply of suitable land, perhaps no more than a third of those in need could have been converted into full-time independent farmers, leaving the rest with little or no land. Under these conditions, the problems in determining which workers should benefit, and the slowness in implementing such a massive reform, were likely to increase, rather than reduce social tensions in the countryside. Indeed, it was attempts by workers' associations to influence the selection process of workers to be settled, that provided syndicates with opportunities to recruit across the region, and culminated in widespread land invasions in $1936^{71}$.

For contemporaries, land reform often had to meet two important, but contradictory objectives, namely the alleviation of short-term rural poverty by maximizing work opportunities, and increasing long-run farm output and efficiency. Questions such as whether rotations should be maintained in an effort to protect soil fertility, or intensified to meet the immediate needs of destitute workers, inevitably divided rural society. However, the limits of land reform as an emergency palliative to cyclical unemployment is also illustrated by the fact that giving a family access to three hectares, such as happened with the Decreto de Intensificación (1932) or the Decretos de Yunteros (3rd and 14th March 1936), provided an income after rent of between 218 and 880 pesetas ${ }^{72}$. Even accepting the agronomists' estimates of wheat yields of 1.14 tons, a figure that was only reached twice in Badajoz between 1910 and 1935, annual income would be just 549 pesetas, or little more than a quarter of family's needs ${ }^{73}$. Marginal cereal cultivation such as this could only have made a material difference to the peasant economy if rent was eliminated, and the land given to the tenants. Given the limited fiscal capacity of the state in 1931 this was not possible in a democratic society.

As this paper shows, it was possible for the IRA to establish settlements and perhaps, if economic and political conditions had been more conducive, then this would have led to an increase in living standards. However, the problem of having to settle asset-poor peasants on farms to pursue a labour intensive agriculture when an increasing number of these had been previously run as capital intensive enterprises suggests that, even under optimal conditions, success would have been limited. The fact that the government produced no feasibility studies before the reform and, with the exception of the partly completed

71. See CARmona and Simpson (2015) and DomeneCh (2015). For land invasions see especially, EsPINOSA (2007).

72. The difference in income depends on whether wheat yields were those that were actually achieved in Badajoz in 1931 (0.78 tons per hectare), or Carrión's estimate (1.5 tons). Rent is estimated at 500 pesetas, and assumes a four year rotation.

73. Agronomists' estimates in Table 4. 
cadastre, had no farm-level information, makes the information collected by the IRA exceptional to understand both the actual state of cultivation on the large estates before reform, and the potential to increase it. It also suggests that if the state had collected information on the nature of local agriculture before the Second Republic, then other policy options might have been tried to reduce rural poverty during the 1930s. Instead with land reform, very few estates were actually expropriated or workers settled, but expectations and political tensions were raised significantly.

\section{ACKNOWLEDGMENTS}

Earlier versions of this work were presented at the IVWorkshop "Cooperación y conflicto en el mundo rural”, Universidad Carlos III de Madrid, 2014; EHS Conference, Wolverhampton, 2015; Agricliometrics II, Zaragoza, 2015; and Rural History, Girona, 2015.

We wish thank in particular Domingo Gallego, Luis Germán, Ricardo Robledo, Mikeas Lana Berasain, and three referees for their comments. In addition, Pilar Bravo Lledó and Pedro Jiménez Clemente greatly facilitated our work in the Archivo de la Reforma Agraria. The authors have benefited from financial assistance Ministerio de Economía y Competitividad ECO2012-36213 and ECO2015-66196-P (MINECO/ FEDER, EU).

\section{REFERENCES}

ABRAMITZKy, R. (2011). Lessons from the Kibbutz on the Equality-Incentives Trade-Off. fournal of Economic Perspectives, 25 (1), 185-208.

Albertus, M., Brambor, T. \& Ceneviva, R. (2016). Land Inequality and Rural Unrest: Theory and Evidence from Brazil. The fournal of Conflict Resolution, 12th July.

AzaÑa, M. (1997). Diarios, 1932-1933: Los cuadernos robados. Barcelona: Crítica.

BALABANiAn, O. (1980). Les exploitations et les problèmes de l'agriculture en Estrémadure espagnole et dans le Haut-Alentejo: Contribution à l'étude de campagnes mediterranéennes. Braga:Typ. Barbosa \& Xavier.

Beltrán, F., IRIARTe, I. \& LANA, J. M. (2014). Memoria y recuperación de bienes comunales: Las interacciones a diferentes niveles y la propiedad de la tierra en la España de los treinta. IVWorkshop "Cooperación y conflicto en el mundo rural. Estado y agricultura en España (1920-1960): Continuidad y cambios”. Madrid: Universidad Carlos III, $17^{\text {th }}-18^{\text {th }}$ November. 
Bernal, A. M. (1979). La lucha por la tierra en la crisis del Antiguo Regimén. Madrid: Taurus.

Bernal, A. M. (1988). Economía e historia de los latifundios. Madrid: Espasa Calpe.

Besley, T. \& Persson, T. (2011). Pillars of Prosperity: The Political Economics of Development Clusters. Princeton: Princeton University Press.

CAmpos, P. (1983). La degradación de los recursos naturales de la dehesa: Análisis de un modelo de dehesa tradicional. Agricultura y Sociedad, (26), 289-380.

Carmona, J., Rosés, J. \& Simpson, J. (2015). Spanish Land Reform in the 1930s: Economic Necessity or Political Opportunism? LSE Economic History Working Papers, (225).

CARmona, J. \& Simpson, J. (2014a). Los contratos de cesión de tierra en Extremadura en el primer tercio del siglo xx. Historia Agraria, (63), 183-213.

CARMONA, J. \& Simpson, J. (2014b). Pósitos agrarios y acción colectiva: Una visión desde el Estado. XI AEHE's International Congress. Madrid, $4^{\text {th }}-5^{\text {th }}$ September.

CARMONA, J. \& Simpson, J. (2015). Organización y funcionamiento de los asentamientos de la Reforma Agraria: La comunidad de campesinos de La Pulgosa en Badajoz, 1933-1941. Revista de Estudios Extremeños, (71), 105-128.

CARMONA, J. \& Simpson, J. (2016). ¿Campesinos unidos o divididos? La acción colectiva y la revolución social entre los yunteros durante la Segunda República en España (1931-1936). Historia Social, (85), 123-144.

CARo, D. (2001). Violencia política y luchas sociales: La Segunda República en Ferez de la Frontera (1931-1936). Jerez: Ayuntamiento de Jerez.

CARRIÓN, P. (1975). Los latifundios en España. Barcelona: Ariel.

Corrionero, F. (1986). El censo de campesinos: La jerarquización del proletariado rural. Studia historica. Historia contemporánea, (4), 181-203.

De Los Ríos, F. (1925). The Agrarian Problem in Spain. International Labour Review, (11), 830-851.

DíAz DEL Moral, J. (1973). Historia de las agitaciones campesinas andaluzas. Madrid: Alianza.

Dirección General del Instituto Geográfico, Catrastral y de Estadística (1932). Censo de la población de España. Tomo 1. Madrid: Instituto Geográfico y Catastral.

Domenech, J. (2015). Land Tenure Inequality, Harvests, and Rural Conflict: Evidence from Southern Spain during the Second Republic (1931-1934). Social History, (39), 253-86.

Dovring, F. (1965). Land and Labor in Europe in the Twentieth Century: A Comparative Survey of Recent Agrarian History. The Hague: M. Nijhoff.

EsPinosa, F. (2007). La primavera del Frente Popular: Los campesinos de Badajoz y el origen de la guerra civil (marzo-julio de 1936). Barcelona: Crítica. 
Espinoza, L. E., Robledo, R., Brel, M. P. \& Villar, J. (2007). Estructura social del campo español: El Censo de Campesinos (1932-1936). Primeros resultados. In R. RoBledo \& S. LóPEZ (Eds.), ¿Interés particular, bienestar público? Grandes patrimonios y reformas agrarias. Zaragoza: Prensas Universitarias de Zaragoza.

Florencio, A. (1994). Empresariado agrícola y cambio económico, 1880-1936. Sevilla: Diputación Provincial de Sevilla.

GEHR (1983a). Notas sobre la producción agraria española, 1891-1931. Revista de Historia Económica, 1 (2), 185-252.

GEHR (1983b). Evolución de la superficie cultivada de cereales y leguminosas en España, 1886-1935. Agricultura y Sociedad, (29), 285-325.

GEHR (1991). Estadísticas históricas de la producción agraria española, 1859-1935. Madrid: Ministerio de Agricultura, Pesca y Alimentación.

GoNZÁLEZ DE MolinA, M. (2014). La tierra y la cuestión agraria entre 1812 y 1931: Latifundismo versus campesinización. In M. GonZÁLEZ DE MOLINA (Ed.), La cuestión agraria en la historia de Andalucía (pp. 21-60). Sevilla: Centro de Estudios Andaluces.

Griffin, K., Rahman KHAN, A. \& Ickowitz, A. (2002). Poverty and the Distribution of Land. Fournal of Agrarian Change, 2 (3), 279-330.

Instituto de Reforma AgRARIA (1934). Datos recopilados sobre las provincias de Badajoz, Cáceres y Huelva. Madrid: s. n.

Lipton, M. (2009). Land Reform in Developing Countries: Property Rights and Property Wrongs. Abingdon: Routledge.

López Estudillo, A. (2002). Crisis finisecular, transformaciones agrarias y atraso económico: Andalucía 1870-1930. In M. GonZÁlez DE Molina (Ed.), La historia de Andalucía a debate. II: El campo andaluz (pp. 137-78). Granada/Barcelona: Diputación Provincial de Granada/Anthropos.

López Ontiveros, A. \& MATA, R. (1993). Propiedad de la tierra y reforma agraria en Córdoba (1932-1936). Córdoba: Universidad de Córdoba.

Macarro, J. M. (2000). Socialismo, republica y revolución en Andalucía. Sevilla: Universidad de Sevilla.

Malefakis, E. (1970). Agrarian Reform and the Peasant Revolution in Spain: Origins of the Civil War. New Haven:Yale University Press.

Martín, J. L. (Dir.) (1997). Documentos sobre la reforma agraria en los archivos del IRYDA. Madrid: UNED.

NARedo, J. M. \& GonzÁlez de Molina, M. (2002). Reforma agraria y desarrollo económico en la Andalucía del siglo xx. In M. GonzÁlez DE Molina (Ed.), La historia de Andalucía a debate. II: El campo andaluz. Granada/Barcelona: Diputación Provincial de Granada/Anthropos.

PALERM, A. (1962). Observaciones sobre la reforma agraria en Italia. Washington: Unión Panamericana. 
Pan-Montojo, J. (2005). Apostolado, profesión y tecnología: Una historia de los ingenieros agrónomos en España. Torrelodones: $\mathrm{B} \& \mathrm{H}$.

Pan-Montojo, J. (2007). Pascual Carrión: Política agraria e ingeniería social. Historia Agraria, (43), 581-598.

Preston, P. (1984). The Agrarian War in the South. In P. Preston (Ed.), Revolution and War in Spain, 1931-1939. London: Methuen.

Riesco, S. (2006). La reforma agraria y los orígenes de la Guerra Civil (1931-1940). Madrid: Biblioteca Nueva.

Robledo, R. (2007). La cuestión agraria en España: De Canalejas a Vázquez Humasqué. Áreas, (26), 95-113.

Robledo, R. (Ed.). (2010). Sombras del progreso: Las huellas de la historia agraria. Ramón Garrabou. Barcelona: Crítica.

Robledo, R. (2014). Sobre el fracaso de la reforma agraria andaluza en la Segunda Republica. In M. GoNZÁLEZ DE MOLINA (Ed.), La cuestión agraria en la historia de Andalucía: Nuevas perspectivas (pp. 61-96): Sevilla: Centro de Estudios Andaluces.

RosiQue, F. (1988). La Reforma agraria en Badajoz durante la II ${ }^{a}$ República: La respuesta patronal. Badajoz: Diputación Provincial de Badajoz.

SÁNCHEZ MARRoYo, F. (1990). Las organizaciones obreras en Extremadura durante la Segunda República. Investigaciones históricas: Época moderna y contemporánea, (10), 123-164.

ScotT, J. C. (1998). Seeing like a State. New Haven:Yale University Press.

SIMPSON, J. (1994). La producción y la productividad agraria españolas, 1890-1936. Revista de Historia Económica, 12 (1), 43-84.

Simpson, J. (1995a). Spanish Agriculture: The Long Siesta, 1765-1965. Cambridge: Cambridge University Press.

Simpson, J. (1995b). Spanish Agricultural Production and Productivity 1890-1936. In P. MARTín-AcEÑa \& J. Simpson (Eds.), The Economic Development of Spain since 1870 (pp. 181-220). London: Edward Elgar.

Simpson, J. \& CARMONA, J. (in preparation). Why democracy fails: The Agrarian Origins of the Spanish Civil War.

SumPSI, J. M. (1978). Estudio de la transformación del cultivo al tercio al de año y vez en la campiña de Andalucía. Agricultura y Sociedad, (6), 31-70.

ZAPATA, S. (1986). La producción agraria de Extremadura y Andalucía Occidental, 18751935. PhD thesis. Madrid: Universidad Complutense de Madrid. 


\section{APPENDIX 1}

Estimate of the impact on incomes of transfers of all lands paying more than 5,000 pesetas tax

\begin{tabular}{lrrr}
\hline & Badajoz & Extremadura & Southern \\
& & & Spain \\
\hline 1. Agricultural families & 128,557 & 206,338 & $1,145,362$ \\
2. Output ('000s pesetas) & 274,278 & 450,821 & $2,544,039$ \\
3. Ricardian rent (33\% output) '000 & 91,426 & 150,274 & 839,533 \\
4. Rent to landowners (\%) $>5.000$ pesetas & 60 & 58 & 40 \\
5. Total rent to landowners $>$ 5.000 & 55,13 & 88,791 & 335,813 \\
6. Nett income per family without redistribution (pesetas) & 1,705 & 1,755 & 1,922 \\
7. Nett income per family with redistribution (pesetas) & 2,134 & 2,185 & 2,221 \\
\multicolumn{1}{c}{ Increase (\%) } & $25 \%$ & $25 \%$ & $16 \%$ \\
\hline
\end{tabular}

Sources: our calculations from Carrión (1975) and Simpson (1995b). 


\section{APPENDIX 2}

\begin{tabular}{|c|c|c|c|c|c|c|c|}
\hline & & & & NUMBER 0 & F SETTLERS & & \\
\hline Settlement & Location & $\begin{array}{c}\text { Distance } \\
\text { from the } \\
\text { village }(\mathrm{km})\end{array}$ & $\begin{array}{l}\text { Area } \\
\text { (ha) }\end{array}$ & $\begin{array}{c}\text { Cultivated } \\
\text { area } \\
\text { (ha) }\end{array}$ & $\begin{array}{l}\text { Cadastral } \\
\text { asessment } \\
\text { (pesetas) }\end{array}$ & Proposed & Final \\
\hline Castillo de Guadajira & Lobón & 5 & 462 & 400 & 118,389 & 65 & 58 \\
\hline Cerrollano & Villanueva del Fresno & 8 & 727 & 707 & 40,808 & 45 & 65 \\
\hline Cuncos & Villanueva del Fresno & 1 & 250 & 250 & 12,479 & 11 & 11 \\
\hline El Pedazo & Villar de Rey & 6 & 316 & 316 & 17,000 & 23 & 23 \\
\hline El Zarzoso & Valle de Matamoros & 7 & 262 & 155 & 25,806 & 14 & 14 \\
\hline Fresnillo y Pinel & Montijo & 3 & 393 & 393 & 46,955 & 58 & 58 \\
\hline Fuente Omendo & Valverde de Leganés & 3 & 309 & 256 & 18,512 & 32 & 32 \\
\hline Guaperal & Roca de la Sierra & 2 & 279 & 279 & 8,737 & 20 & 20 \\
\hline La Dehesilla & Santo Domingo (Olivenza) & 3 & 353 & 320 & 17,654 & 16 & 8 \\
\hline La Frada & Valverde de Leganés & 6 & 41 & 40 & 2,317 & 7 & 7 \\
\hline La Mata & Fuente de Cantos & 3 & 430 & 430 & 21,179 & 19 & 19 \\
\hline La Pulgosa & Barcarrota & 5 & 892 & 680 & 56,622 & 28 & 39 \\
\hline Lapas y Risquillos & Villanueva del Fresno & 9 & 493 & 460 & 26,100 & 45 & 45 \\
\hline Las Borrachinas & Alconchel & 5 & 376 & 300 & 16,085 & 22 & 15 \\
\hline Las Cabras (Alta and Baja) & Zahínos & 8 & 2,704 & 2,600 & 107,000 & 235 & 527 \\
\hline Los Tocinillos & Fregenal de la Sierra & 14 & 285 & 180 & 15,600 & 29 & 16 \\
\hline Magistrada & Olivenza & 8 & 103 & 64 & 3,232 & 3 & 3 \\
\hline Margaritas & Valle de Santa Ana & 0.5 & 500 & 200 & 26,675 & 32 & 32 \\
\hline Merinillas Altas & Valverde de Leganés & 2 & 596 & 596 & 29,798 & 119 & 119 \\
\hline Monte Encinar de Villalba & Villalba de los Barros & 4 & 435 & 435 & 29,110 & 24 & 24 \\
\hline Naveperas & Villanueva del Fresno & 7 & 662 & 420 & 21,604 & 27 & 27 \\
\hline Palacito & Roca de la Sierra & 2.5 & 254 & 154 & 14,712 & 22 & 22 \\
\hline Quinto de Almadén & Alange & 7 & 437 & 407 & 19,341 & 33 & 33 \\
\hline Ramira Alta & Higuera de Vargas & 8 & 1,004 & 1,004 & 35,603 & 71 & 560 \\
\hline Represa & Villanueva del Fresno & 5 & 629 & 629 & 21,860 & 78 & 70 \\
\hline Santisfolla de la Rueda & Montijo & 6 & 135 & 94 & 9,758 & 23 & 23 \\
\hline Señorío y Taldarrobas* & Torremejías & 0 & 2,855 & 1,776 & 87,143 & 250 & 250 \\
\hline Tablado y Capilla & Jerez de los Caballeros & - & 490 & 445 & 28,790 & 17 & 17 \\
\hline Vadevesevilla del Monte/La & Villanueva del Fresno & 7 & 690 & 690 & 23,905 & 54 & 54 \\
\hline
\end{tabular}




\begin{tabular}{|c|c|c|c|c|c|c|c|c|}
\hline \multirow[b]{3}{*}{$\begin{array}{l}\text { Cultivated } \\
\text { area/ } \\
\text { settler (ha) }\end{array}$} & \multicolumn{8}{|c|}{ INSTITUTIONAL LOANS (1933-36) } \\
\hline & \multicolumn{4}{|c|}{ Fixed capital } & \multicolumn{3}{|c|}{ Working capital } & \multirow[b]{2}{*}{$\begin{array}{l}\text { Total } \\
\text { loans }\end{array}$} \\
\hline & $\begin{array}{l}\text { Cadastral } \\
\text { assessment per } \\
\text { settler (pesetas) }\end{array}$ & Machinery & Animals & $\begin{array}{c}\text { Seeds } \\
\text { and } \\
\text { fertilizers }\end{array}$ & Settlers & Fodder & Others & \\
\hline 6.9 & 2041 & 2,110 & 6,224 & 1,867 & 10,708 & 3,305 & 1,324 & 25,538 \\
\hline 10.9 & 628 & 12,525 & 24,203 & 19,497 & 3,000 & 27,444 & 14,696 & 101,365 \\
\hline 22.7 & 1134 & 3,420 & 14,812 & 4,992 & 5,850 & 7,773 & 10,497 & 47,344 \\
\hline 13.7 & 739 & 2,443 & 30,125 & 4,178 & 17,530 & 14,467 & 1,372 & 70,115 \\
\hline 11.1 & 1843 & 1,113 & 38,500 & 5,156 & 8,664 & 15,544 & 7,980 & 76,957 \\
\hline 6.8 & 810 & 10,900 & 0 & 19,004 & 37,691 & 14,477 & 0 & 82,072 \\
\hline 8.0 & 579 & 8,757 & 13,510 & 12,755 & 18,007 & 9,082 & 5,413 & 67,524 \\
\hline 14.0 & 437 & 7,300 & 21,460 & 5,887 & 16,690 & 8,562 & 940 & 60,839 \\
\hline 40.0 & 2207 & 846 & 18,892 & 3,980 & 0 & 3,308 & 973 & 27,999 \\
\hline 5.7 & 331 & 2,079 & 2,100 & 2,105 & 3,500 & 2,222 & 4,800 & 16,806 \\
\hline 22.6 & 1115 & 3,979 & 17,711 & 10,647 & 15,450 & 7,728 & 1,580 & 57,095 \\
\hline 17.4 & 1452 & 0 & 81,623 & 20,190 & 60,200 & 8,879 & 5,145 & 176,037 \\
\hline 10.2 & 580 & 8,737 & 17,313 & 14,123 & 23,169 & 11,663 & 5,007 & 80,012 \\
\hline 20.0 & 1072 & 4,425 & 22,259 & 11,526 & 16,200 & 17,015 & 4,097 & 75,522 \\
\hline 4.9 & 203 & 0 & 199,378 & 74,635 & 0 & 14,000 & 44,127 & 332,140 \\
\hline 11.3 & 975 & 3,600 & 14,525 & 7,876 & 14,585 & 3,731 & 933 & 45,250 \\
\hline 21.3 & 1077 & 2,199 & 2,837 & 596 & 751 & 826 & 0 & 7,209 \\
\hline 6.3 & 834 & 5,050 & 67,000 & 6,519 & 7,828 & 22,862 & 14,420 & 123,679 \\
\hline 5.0 & 250 & 20,808 & 17,843 & 40,901 & 38,700 & 23,864 & 4,708 & 146,824 \\
\hline 18.1 & 1213 & 12,690 & 27,425 & 11,117 & 26,495 & 26,325 & 18,230 & 122,282 \\
\hline 15.6 & 800 & 5,619 & 39,000 & 7,975 & 20,972 & 9,830 & 13,020 & 96,416 \\
\hline 7.0 & 669 & 5,600 & 21,300 & 6,731 & 4,400 & 8,537 & 1,763 & 48,331 \\
\hline 12.3 & 586 & 16,735 & 16,100 & 11,547 & 11,880 & 18,694 & 8,262 & 83,218 \\
\hline 1.8 & 64 & 0 & 40,000 & 31,219 & 18,325 & 1,477 & 1,680 & 92,701 \\
\hline 9.0 & 312 & 0 & 0 & 21,299 & 36,655 & 0 & 476 & 58,430 \\
\hline 4.1 & 424 & 3,728 & 4,024 & 8,169 & 9,608 & 4,884 & 285 & 30,698 \\
\hline 4.1 & 424 & 38,070 & 45,000 & 29,689 & 80,809 & 29,000 & 131,793 & 354,361 \\
\hline 26.2 & 1694 & 2,744 & 41,659 & 6,281 & 13,375 & 13,826 & 259 & 78,144 \\
\hline 12.8 & 443 & 12,703 & 29,879 & 19,980 & 10,189 & 19,189 & 5,010 & 96,950 \\
\hline
\end{tabular}

^Loans were aproved but not received.

Figures in bold type indicate our estimates.

Sources: AIRA, Monografías, box 6.7. 